\title{
Scientists, activists sue South Africa's AIDS 'denialists'
}

Doctors and AIDS activists in South Africa have filed a joint lawsuit against the country's health minister and controversial vitamin supplier Matthias Rath as concerns mount over the government's lack of leadership amidst the country's worsening AIDS crisis.

The South African Medical Association (SAMA) and the prominent activist group Treatment Action Campaign (TAC), which together filed the lawsuit, say they aim to end the climate of what the TAC calls "politicallysupported denialism" afflicting the country's fight against AIDS.

A key element of the lawsuit is the allegation that in at least two townships, Rath is running illegal medical trials for his multivitamins, which he markets to AIDS sufferers as an alternative to 'poisonous' antiretroviral drugs.

Rath has promoted these trials through several newspaper advertisements, claiming that a combination of micronutrients alone can reverse the course of AIDS, even in its advanced stage. But the TAC says five or more patients have died during these trials.

"There are reports of up to 12 deaths, but it's hard to say," says TAC spokesman Nathan Geffen. "We hold [Rath] partially accountable for two to three of them. In the other cases, we feel they created false hopes," he says.

Two patients from the trial, still alive and held up by Rath as models of success, were found to actually be taking antiretroviral drugs, according to the TAC.

Separately, health minister Manto Tshabalala-Msimang has long provoked outrage with her public support of garlic, lemon and beetroot as defenses against AIDS, as well as her ongoing affiliations with denialists like Rath. "We want the court to put an end to governmentsupported charlatanism," says Geffen.

SAMA spokesman Mark Sonderup says the legal process is an attempt to get various agencies under the health minister's control, such as the Medicines Control Council, to properly investigate Rath's activities. "As the representative body of doctors in South Africa we have a principled duty to respond to what is going on," Sonderup says.

A spokesman for Rath declined to speak to Nature Medicine about the case, saying he is convinced the journal is "funded to the hilt with drug money."

Although the lawsuit is not expected to reach the court for some months, the TAC and SAMA have already gained public backing from several prominent groups, including the country's largest trade union, a major church council and various non-governmental organizations.
South Africa hosts an estimated 5.3 million HIV-infected individuals, the most for any country. A UNAIDS report released on 21 November says the country's epidemic has evolved at an astonishing speed, from a prevalence of less than $1 \%$ in 1990 to $25 \%$ by 2000 .

The country's budget for AIDS has more than tripled since 2001 to R1.5 billion (about $\$ 235$ million). In March the government spent R3.4 billion (about $\$ 533$ million) to acquire a three-year stock of antiretroviral drugs. Experts estimate these drugs are provided to about 140,000 people, a significant increase from a year earlier-but still far behind the government's own rollout targets.

James Watson, London

\section{Low morale at US agency revives dormant scientist group}

Driven by an increasingly demoralized environment at the US National Institutes of Health, a group of researchers at the agency have banded together to champion their cause. The group's leaders say their goal is to boost spirits and preserve the agency's ability to recruit and retain top scientists.

The Assembly of Scientists, a reincarnation of several organizations launched in the late 1950 s, lay dormant for nearly 30 years. But in November 2004, amid rumors of an impending clampdown on financial consulting, Ezekiel Emanuel, chair of NIH's clinical bioethics department, fired off a fuming letter to NIH director Elias Zerhouni and revived the group with the help of 200 colleagues .

In theory, more than 2,000 NIH scientists are automatically considered members of the group, and at the first meeting in January 2005 , at least 700 scientists were in attendance, either in person or via video conference. Since then, the organization has adopted new bylaws, elected a 12-member advisory council and begun soliciting donations.

Among the group's goals is to retain the uniformed commissioned corps of the US Public Health Service, who routinely work at NIH. These scientists are deemed first responders and must move quickly to hurricane and other disaster areas. The scientists used to be able to retire after 20 years and become NIH employees, but for reasons that are unclear, this has since become difficult. "We are losing more and more of these individuals and they constitute the bulk of clinical investigators," says Alan Schechter, chief of molecular biology at the National Institute of Diabetes \& Digestive \& Kidney Diseases.

Another hot-button topic is the restrictions on travel to meetings. Unlike employees of many other agencies, NIH scientists must fly coach unless the trip is longer than 14 hours on a single leg. Schechter, a 40 -year veteran at the NIH, recently canceled a trip to Vietnam because of the rules. "In the end the biggest factor was that I just did not have the energy at my age to fly coach from Washington to Hong Kong," he says.

An NIH spokesperson said, “These are real concerns of our scientists and are being addressed," but declined to comment on specific complaints.

Discontent has been brewing at the NIH for a few years but came to a head after a series of press reports uncovered conflict-of-interest violations at the agency. In response, the $\mathrm{NIH}$ initially proposed restrictive rules on the financial arrangements, revising them in August to a more relaxed set (Nat. Med. 11,914-915).

Still, a number of problems affect the mood at the NIH, says Emanuel. "Each one of these is a worrisome situation," he says. "I don't think that changing parts of the conflict- ofinterest rule is going to be sufficient to boost morale."

George S. Mack, Columbia, South Carolina 